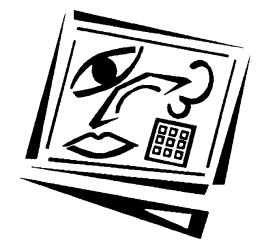

\title{
Using multimedia in a constructivist learning environment in the Malaysian classroom
}

\author{
Ken Neo Tse-Kian \\ Multimedia University, Malaysia
}

\begin{abstract}
In recent years, the infusion of multimedia into teaching and learning has altered considerably the instructional strategy in our educational institutions and changed the way teachers teach and students learn. The traditional teacher-centric method of teaching used for decades in our educational system has been modified and enhanced. Currently, modern education theory is moving from the traditional recall of facts, principles, or correct procedures into the areas of creative thinking, problem solving, analysis and evaluation. These are skills which are very much needed in today's knowledge based economy. This shift in focus on learning has presented Malaysian educators with serious challenges as well as opportunities in restructuring their curriculum to meet the rising demands of the knowledge based society, which is currently being initiated by the Malaysian Government.
\end{abstract}

In this paper, we focus on designing a course which is oriented towards a constructivist based paradigm by using multimedia as an instructional tool, and where students are active learners, involved in constructing their own knowledge in the learning process and determining how to reach their own learning outcomes. A survey was carried out to ascertain the reactions of students enrolled in an interactive multimedia course in the Multimedia University, Malaysia towards this constructivist based learning mode. The results indicated that these students reacted positively towards this study mode and improved their interpersonal and collaborative learning skills.

\section{Introduction}

In the last three decades, PC and multimedia technologies have progressed by leaps and bounds. With this rapid progress, it has now become feasible and affordable to integrate multimedia technology into the teaching and learning process. This infusion of multimedia into teaching and learning has altered considerably the instructional strategy in our educational institutions and changed the way teachers teach and students learn. Many colleges and universities, including those in 
Malaysia, are currently moving towards using digital technology to enhance teaching and learning (Kachian \& Wieser, 1999; Johns, 1999; Mat, 2000; Cook \& Cook, 1998; Oliver, 2000).

The traditional teacher-centric method of teaching, as used for decades in our educational system, has been modified and enhanced. Current modern educational theory is moving from the traditional recall of facts, principles, or correct procedures into the areas of creative thinking, problem solving, analysis and evaluation (Bates, 2000). These are skills which are very much needed in today's knowledge based economy (k-economy). This shift in focus on learning from the behavioural to the constructivist perspective has presented Malaysian educators with serious challenges as well as opportunities in restructuring their curriculum to meet the rising demands of the k-economy, although the traditional "chalk and talk" mode of teaching is still widely used in many institutions of higher learning. This is revolutionising our classrooms in Malaysia and providing Malaysian students with new and rich learning experiences and enabling them to have more depth and direction in their learning process.

In this paper, we investigate the impact of such a learning environment on student learning in the Multimedia University, Malaysia, via a multimedia project aiming to marry technology and the teaching and learning process. By effectively integrating multimedia technology into the curriculum, teachers will have more flexibility and scope in teaching and a constructivist learning environment can be created (Thornburg, 1995), where learning becomes "a social activity, facilitated by a new breed of educators" (Tapscott, 1999). These educators act as guides to facilitate and support student learning rather than only being experts providing content and information, as in the traditional directed instruction model.

\section{The constructivist learning paradigm}

The traditional teacher-centric way of teaching and learning is the 'chalk and talk' method and the instructional medium used is mainly textual (printed books). This is the directed instruction model, which is a popular technique used as an educational strategy for decades in our institutions of learning. Basically, the teacher controls the instructional process, the content is delivered to the entire class and the teacher emphasises factual knowledge. In other words, the teacher is regarded as the source of expert knowledge which is communicated to the students through lectures in a classroom environment, where students obediently listen to the lecture. Thus, the learning mode tends to be passive and the learners play little part in their learning process. The focus is on the content, i.e. how much material has been delivered and how much the students have learned. 
On the other hand, the constructivist learning mode describes a learning process whereby students work individually or in small groups to explore, investigate and solve authentic problems and become actively engaged in seeking knowledge and information, rather than being passive recipients. In this process, the learners must play an active part in their learning process and be autonomous learners who are actively engaged in constructing new meaning within the context of their current knowledge, experiences and social environments. Learners become successful in constructing knowledge through solving problems that are realistic, and usually work in collaboration with others. This constructivist learning approach has its foundations in cognitive learning psychology (Jonassen, Peck \& Wilson, 1999), and its roots in theories by Dewey (1896), Piaget (1952), Bruner (1985), Vygotsky (1978) and Papert (1980). Generally, constructivist learning places emphasis on the learners and proposes that learning is affected by their context, their beliefs and their attitudes. Learners are encouraged to find their own solutions and to build upon their prior knowledge and experiences. In a constructivist learning environment, students learn by fitting new information together with what they already know and actively construct their own understanding. In doing so, they gain a deeper understanding of the event and thereby constructing their own knowledge and solutions to the problems (Duffy \& Jonassen, 1991; Jonassen, 1994).

Constructivist learning is categorised mainly into cognitive constructivism and social constructivism. Cognitive constructivism is based upon the works of pyschologist Jean Piaget (1952) and later, in educational computing, of Seymour Papert (1980). It describes a theory of development whereby learners build their own knowledge by constructing mental models, or schemas, based on their own experiences. These schemas are then developed, modified and made more sophisticated over time. Cognitive constructivism focusses on the individual's mental construction of knowledge, whilst social constructivism enlarges that view by placing more emphasis on the social context of the learning environment. Based on the works by Lev Vygotsky (1978), social constructivism emphasises Vygotsky's Zone of Proximal Development (ZPD), which argues that students can, with the help of adults or more advanced students, master concepts and ideas that they cannot understand on their own, and states that, "What the child is able to do in collaboration today, he will be able to do independently tomorrow" (Vygotsky, 1987; Hung, 2001). In other words, students learn by interacting with their more capable peers, teachers and experts in a collaborative learning community. 


\section{The instructional relationship}

In this constructivist based learning mode, the instructional relationship between the teacher and the students is quite different. The role of the teacher becomes more complex as it involves the management of the learning environment, providing instruction and scaffolding activities, monitoring feedback and progress, and assessing students' performance. Students, on the other hand, play an active part and assume more responsibility for their own learning. They seek information and construct knowledge on their own based on their previous experience and interact actively with their peers and teacher to enhance their learning process. In other words, they become more autonomous and independent seekers of information and knowledge. The technology used plays the role of an enabler, providing sufficient resources to ensure successful establishment of the learning environment. The author's model to illustrate this complex relationship is shown in Figure 1.

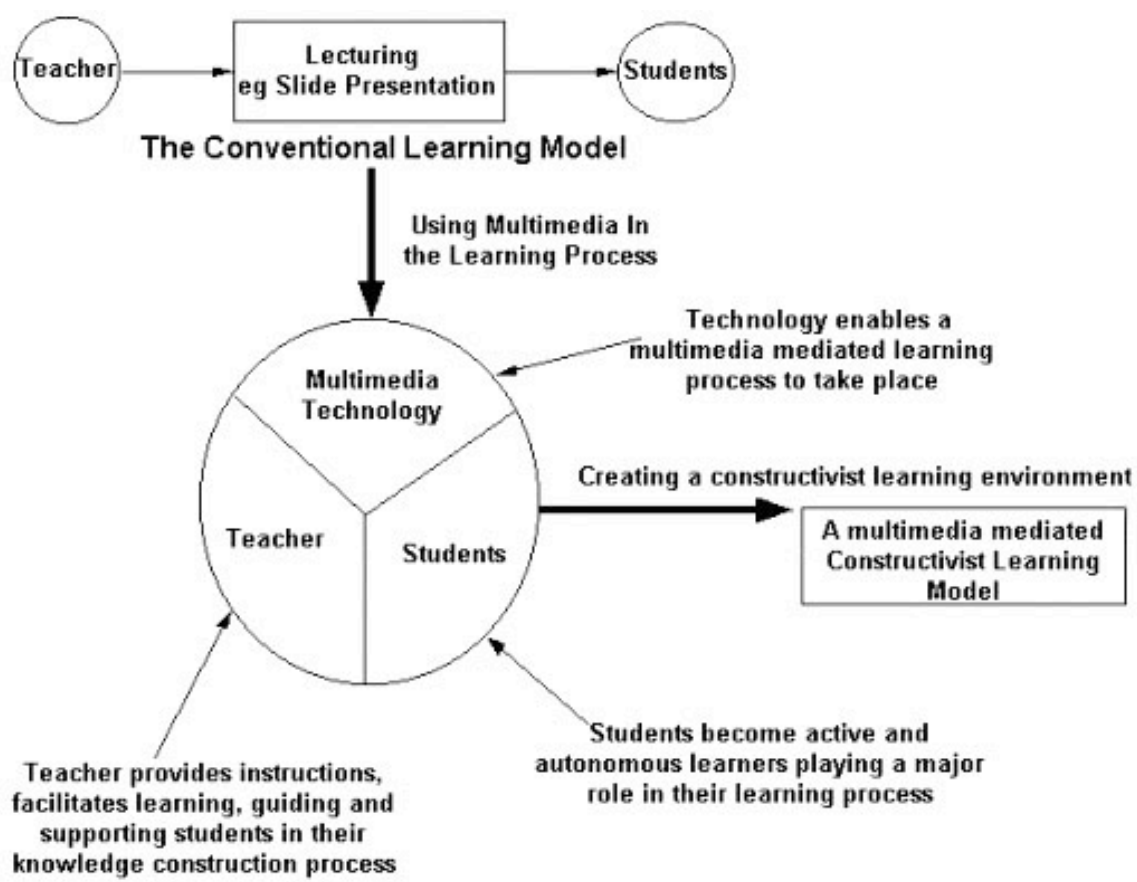

Technology backed Learning Process

Figure 1: The instructional relationship between the teacher, students and technology in the conventional and multimedia mediated constructivist learning modes 
With constructivist learning, the emphasis in learning is upon the students who are active learners, seeking information and knowledge on their own, determining how to reach the desired learning outcomes themselves and not relying on teachers to supply them with information. Here, students become active participants in their own learning processes and learn to solve problems and work collaboratively with their peers. Learning takes place in a meaningful, authentic context and is a social, collaborative activity, where peers play an important role in encouraging learning. In this respect, the teacher is no longer perceived as the sole authority of learning, but, rather, as the person to facilitate learning, guiding and supporting learners' own construction of knowledge (Orlich, Harder, Callahan \& Gibson, 1998).

In this mode, the focus is on the learning process rather than on the content, on learning 'how to learn' rather than 'how much is learned'. This environment encourages students to develop critical thinking, problem solving and team skills, with technology being integral to their learning.

\section{The class project: Creating the constructivist based learning environment}

The emergence of multimedia technologies has made it very possible for learners to become involved in their work. With multimedia technologies, they can create multimedia applications as part of their project requirements. This would make them active participants in their own learning process, instead of just being passive learners of the educational content. It also fosters collaborative and cooperative learning between and among students, thus better preparing them with a skillset for real life work situations (Roblyer \& Edwards, 2000).

With multimedia projects, students can make use of the knowledge presented to them by the lecturer, and represent them in a more meaningful way, using different media elements. These media elements can be converted into digital form and modified and customised for the final project. By incorporating digital media elements into the project, students are able to learn better since they use multiple sensory modalities, which would make them more motivated to pay more attention to the information presented and better retain the information. Therefore, multimedia application design offers new insights into the learning process of the designer and forces him or her to represent information and knowledge in a new and innovative way (Agnew, Kellerman \& Meyer, 1996).

In this Malaysian case study, the class consisted of 46 students in their second year at the Faculty of Creative Multimedia (FCM) in the 
Multimedia University taking a course in interactive multimedia. The university, which was established about 6 years ago, is situated in the heart of the Malaysian Multimedia SuperCorridor (the MSC). This MSC is an IT centre like the Silicon Valley in USA, and will be connected electronically to the world at large. The Multimedia University is one of its key projects and is established to provide students with multimedia and IT courses using the state of the art technologies. To create the constructivist learning environment in the classroom, students were given a multimedia application project to complete. Here the students chose their own project theme and worked in groups of 4-6 people. Each group had to decide on their group members, their team topic and use a multimedia authoring tool, Macromedia Director, as the tool to create the final project and deliver it on a CD. This project was to be completed in 14 weeks (one trimester).

These students have no a priori knowledge in multimedia authoring and authoring tools and, therefore, were given lectures and tutorials to provide them with basic skills in multimedia application development. They did however, have prior experience in design and other multimedia software such as Adobe Photoshop (for graphics), Premier (for digital video), Macromedia Flash (for animations) and SoundForge (for sound), which they can utilise together with Director to develop their projects. The students also had to harness their team skills to work together towards their collective group goals. As a group, students had to decide on the concept of the presentation, the design of the presentation interface and navigation, and the appropriate digital multimedia elements and interactive features to use to best convey their topic of interest. They also had to decide on a group leader and assigned various tasks to their members. These included tasks such as "Graphic Designer", "Sound Engineer", "Researcher" and "Producer."

\section{Students' multimedia development process}

This constructivist based learning environment was created to empower these students to become autonomous, independent learners involved in their own learning process, as well as to develop their skills in problem solving, and to exercise analytical, critical and creative thinking in their work. The project is in line with the constructivist position in that multiple perspectives to an authentic problem can be developed, the use of multiple modes such as audio, graphics and video is encouraged, and students can actively participate to provide their own solutions to the problem (Cunningham, Duffy \& Knuth, 1993). Thus, by designing a multimedia project, students are challenged to learn more about their chosen subject material and to develop their abilities to organise, analyse and synthesise their work in a group setting. 
The multimedia development process (MDP) that the students undertook to create their applications is as follows:

1. Project conceptualisation. Here the teams and their group leaders discussed the topics that were of interest to them and selected the one that everyone could agree upon to do. After deciding on their topics of interest, the various teams then developed storyboards to conceptualise their ideas. These storyboards were presented to the lecturer for consultation. From these storyboards, the interactive application was developed.

2. Planning,organising and research. The groups then organised their schedules, planned their meetings, discussions and brainstorming sessions, divided the team work and carried out research activities such as interviews and information gathering on their topics from various sources such as printed books and the Internet.

3. Developing digital media content. After collecting the necessary data, the groups then dicussed and decided on the combination of media elements (text, graphics, sound, video, animation) to use to best convey their data, and set about creating those elements. Many of them utilised multimedia helper applications such as Adobe Photoshop, Premier and Macromedia Flash to create these digital media elements. For materials that came from analogue sources, such as VHS tapes and brochures, conversions were made to digital format and edited.

4. Multimedia authoring. After all the elements had been created and the information was successfully digitised, the final, interactive multimedia application was then authored using the authoring tool Director. Here, groups referred back to their storyboard and authored their applications accordingly. Interactive features were embedded to create an experiential environment. These included hot spots, hypertext and pull down menus.

5. Packaging and delivery. The final application was then packaged as a standalone application ( ${ }^{*}$.EXE) and "burned" onto a CD for delivery.

6. Presentation. At the end of the project, each group made an oral presentation of their final product to the teacher and their peers who then made critical comments on their projects. This enabled students to reflect on their overall performances.

The role of the teacher in this class was that of a facilitator and consultant to these students. The teacher and students met twice a week to discuss their group projects and to consult on any issues or concerns that they may have encountered. 


\section{A conceptual model of the constructivist learning environment}

In the process of creating the constructivist learning environment, a conceptual model representing this learning mode was constructed by the author as shown in Figure 2. This learning model depicts the students' learning process and incorporates the multimedia development process.

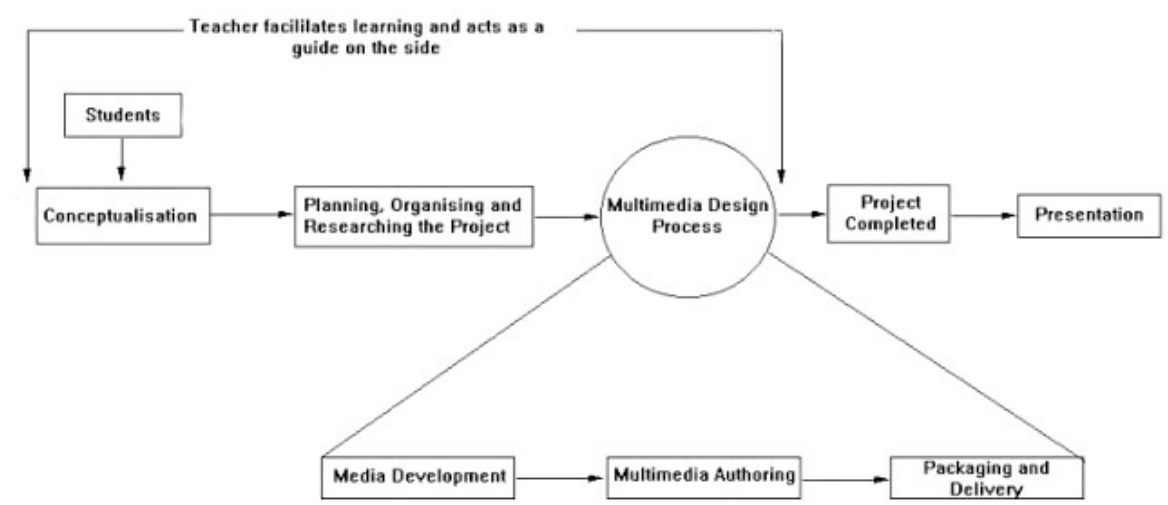

Figure 2: The multimedia mediated model of the constructivist learning mode

\section{Showcase: Student projects}

The final interactive applications that were developed by these groups included many topics. One group, for example, developed an interactive application on a Malaysian traditional game named Congkak. The design of the application follows closely its theme of traditionalism, with sections on "Background", "Types" (as in variations in the game itself), "How To Play" (which gives detailed information on how to play the game), "Play The Game" (which is an interactive section showing an animation of the game being played), "The Future" of the game, and "End Credits" which displays the members of the group and their tasks in the application (Figure 3).

As shown in the Figures $3 a, 3 b$ and $3 c$, the application is both interactive and multimedia oriented, beginning with a creative menu page showing a tree branch. Here the user can rollover various branches of the tree with the mouse in order to see the different menu options in the application (see Figure 3a). Choosing the option "How To Play", or example, will bring the user to the game playing section where an interactive game of the congkak is provided as well as explanantions on how to play the game and win (see Figure 3b). Similarly, the option on the "Types" of craftsmanship involved in creating the game is depicted with colourful graphics and textual explanations (see Figure 3c). 


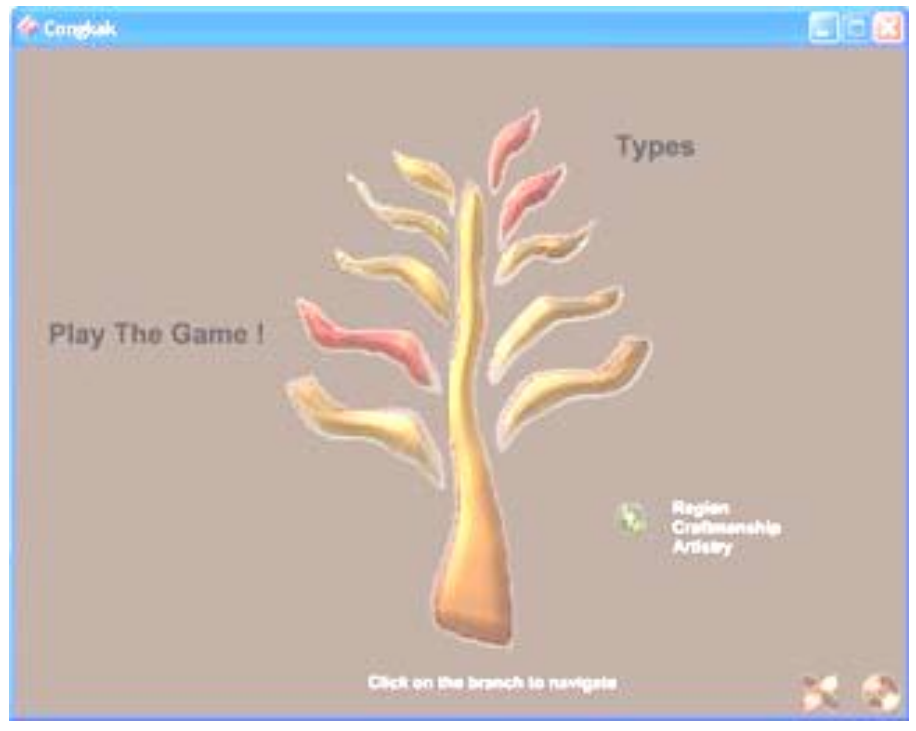

Figure 3a: The menu page for one group's interactive multimedia application on a traditional Malaysian game, Congkak

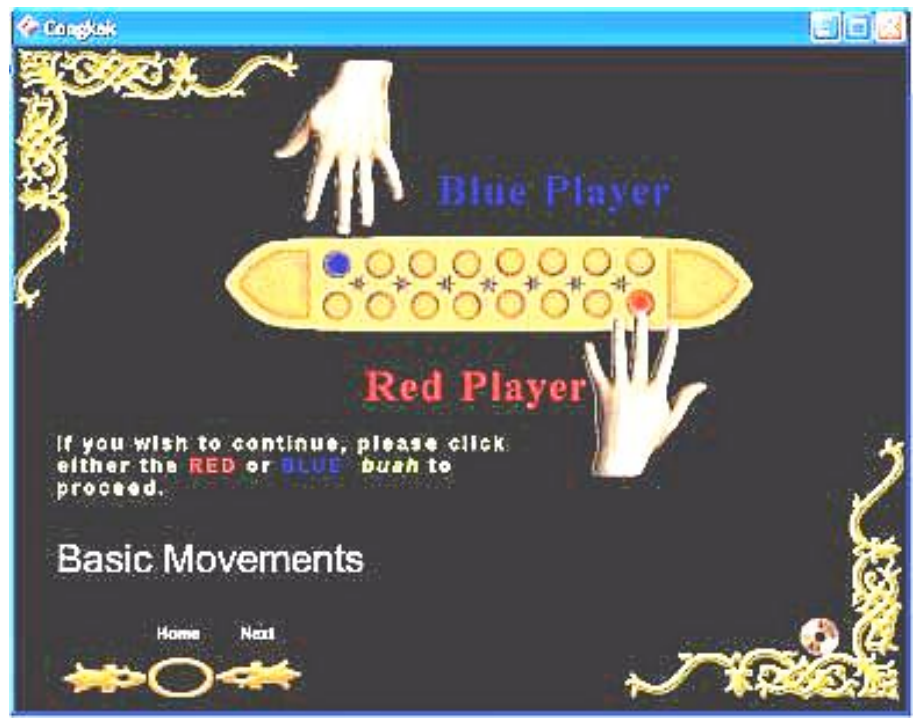

Figure 3b: Screen on "Playing the Game"

(obtained from menu item "Play The Game" in Figure 3a screen picture) 


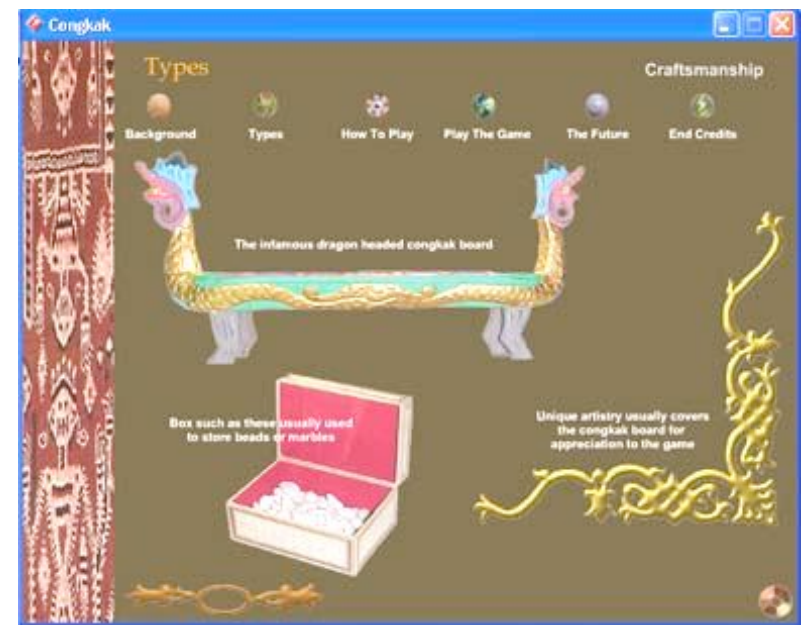

Figure 3c: The various types of craftsmanship involved in the game (obtained from menu item "Types" in Figure 3a screen picture)

Another group concentrated on developing their interactive multimedia application around the topic of The Straits Chinese (see Figures $4 \mathrm{a}, 4 \mathrm{~b}$ and 4c). Here students focussed on the traditions and culture of early Chinese settlement in Malacca, Malaysia. The design of the interface is also fairly traditional, with interactive buttons created to link the user to the various pages in the application, including "Daily Activites," "Food", "Custom" and "Architecture".

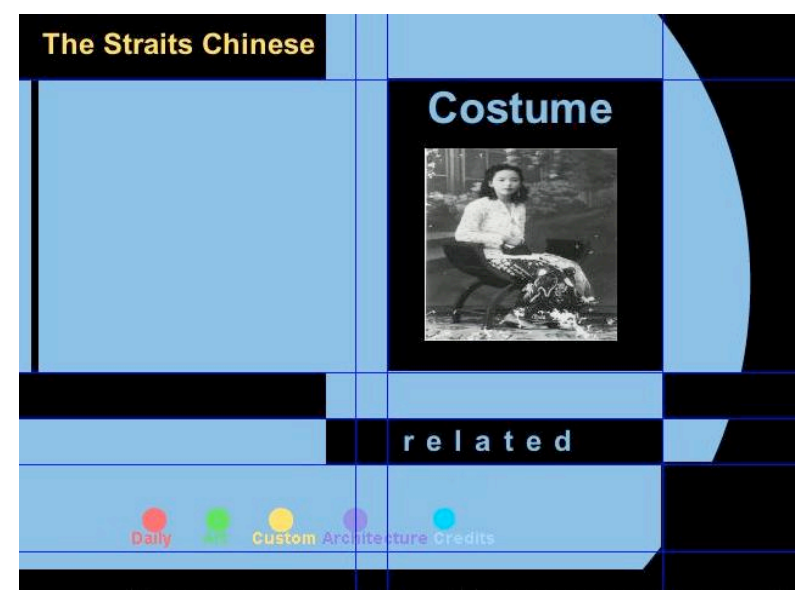

Figure 4a: A menu page for another group's interactive multimedia application on The Straits Chinese of Malaysia 


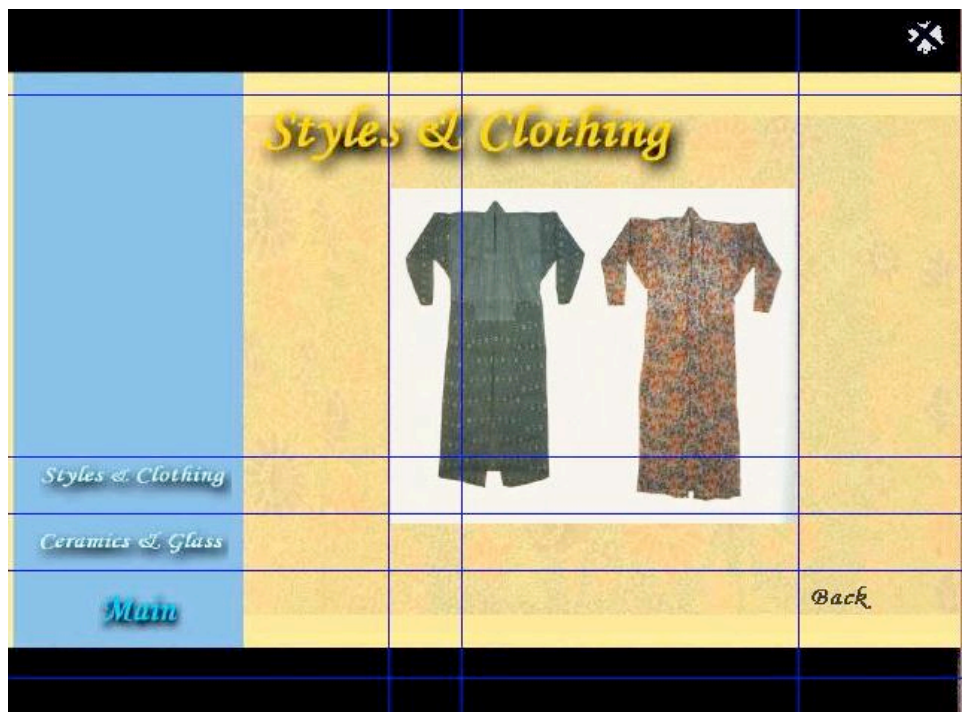

Figure 4b: Link to the "Custom" section

(obtained from menu item "Custom" in Figure 4a screen picture)

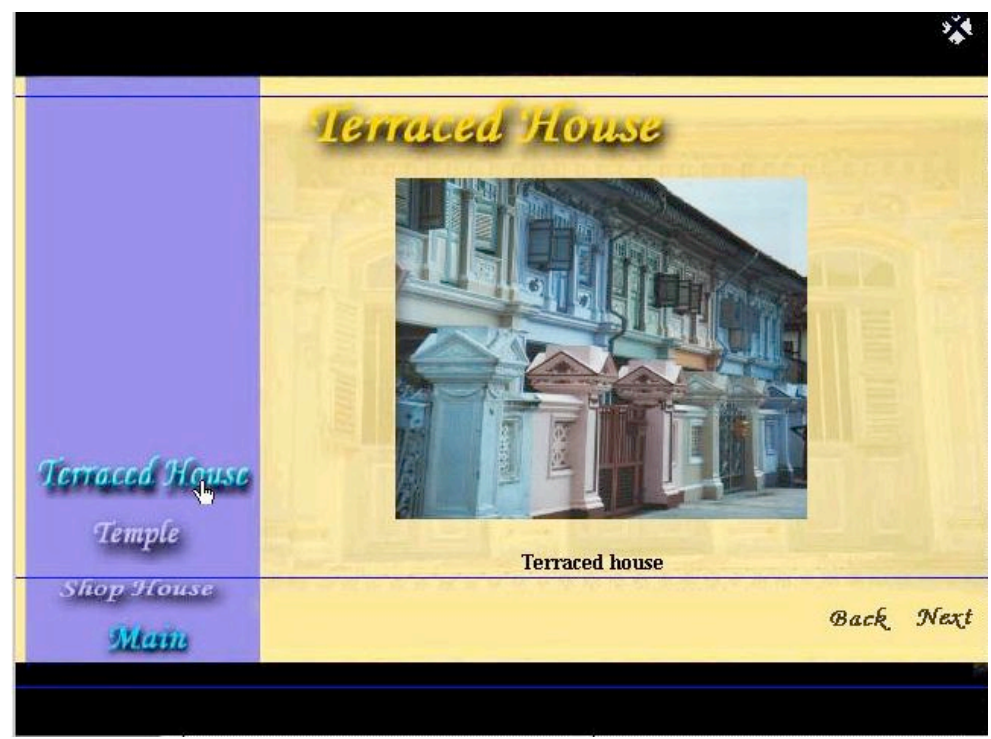

Figure 4c: Link to the "Architecture" section (obtained from menu item "Architecture" in Figure 4a screen picture) 


\section{Assessment and results}

The students' projects were assessed over several criteria. These included originality of the project, creativity of the project's concept, effective use of the authoring tool and other multimedia helper applications, depth of content in the application and documentation, proper representation of the content via media elements, teamwork and group management, level of difficulty in application's navigation and interactivity, and overall presentation of digital application and documentation.

Overall, the class did well in their projects which were demonstrated by the student projects presented here (see Figures $3 a, 3 b, 3 c$, and Figures $4 a$, $4 \mathrm{~b}, 4 \mathrm{c})$. These results were consistent with their performance in the course, where those who scored high overall results in the class also scored high marks for their projects.

\section{Evaluation of student learning}

The constructivist based learning environment was also evaluated via a survey designed to assess the students' attitudes towards the project and working in groups. The sample size was 46 students $(\mathrm{N}=46)$. The survey was measured using a 5 point Likert scale, with 1 for Strongly Disagree (SDA), 2 for Disagree, 3 for Undecided, 4 for Agree and 5 for Strongly Agree (SA). These questions made up several constructs to measure the students' problem solving skills, collaborative efforts and teamwork. The survey questions were adapted from Diamond (1998, pp.144). These were given to students using a questionnaire distributed in class after completion and presentation of their projects. This gave time for the students to reflect on their works and performances before the survey was carried out. Data were collected and anlaysed using SPSS version 10.

Table 1: Means and percentages for the construct "Creative and Critical thinking"

\begin{tabular}{|l|c|c|}
\hline \multicolumn{1}{|c|}{ Items } & $\begin{array}{c}\text { Means }(\mathrm{m}) \\
(\mathrm{N}=46)\end{array}$ & $\%(\mathrm{p})$ \\
\hline 1. Understood subject better after project & 3.98 & 89 \\
\hline 2. Project allowed me to be think critically about the topic & 3.98 & 83 \\
\hline 3. Project enhanced my understanding of the subject & 3.98 & 89 \\
\hline 4. Project allowed me to be creative in my thinking & 4.15 & 91 \\
\hline 5. Able to have creative input & 4.02 & 83 \\
\hline
\end{tabular}

Tables 1, 2 and 3 illustrate the means yielded for the different constructs measured and Figures 5,6 and 7 illustrate the percentage response on the survey scale obtained for one of the items measured in each construct category. 
Table 2: Means and percentages for the construct "Teamwork"

\begin{tabular}{|l|c|c|}
\hline \multicolumn{1}{|c|}{ Items } & $\begin{array}{c}\text { Means }(\mathrm{m}) \\
(\mathrm{N}=46)\end{array}$ & $\%(\mathrm{p})$ \\
\hline 1. The group was able to achieve its goals & 3.83 & 76 \\
\hline 2. Able to learn more working with teammates & 3.83 & 78 \\
\hline 3. Team able to create project with existing software & 3.85 & 76 \\
\hline 4. Satisfied with own contribution to team & 3.98 & 82 \\
\hline
\end{tabular}

Table 3: Means and percentages for the construct "Motivation and technology use"

\begin{tabular}{|l|c|c|}
\hline \multicolumn{1}{|c|}{ Items } & $\begin{array}{c}\text { Means }(\mathrm{m}) \\
(\mathrm{N}=46)\end{array}$ & $\%(\mathrm{p})$ \\
\hline 1. Felt very motivated doing this project & 3.98 & 76 \\
\hline 2. Found the project challenging & 4.17 & 91 \\
\hline 3. Better able to represent concept using digital multimedia & 4.15 & 91 \\
\hline 4. Look forward to working on the project & 4.09 & 91 \\
\hline
\end{tabular}

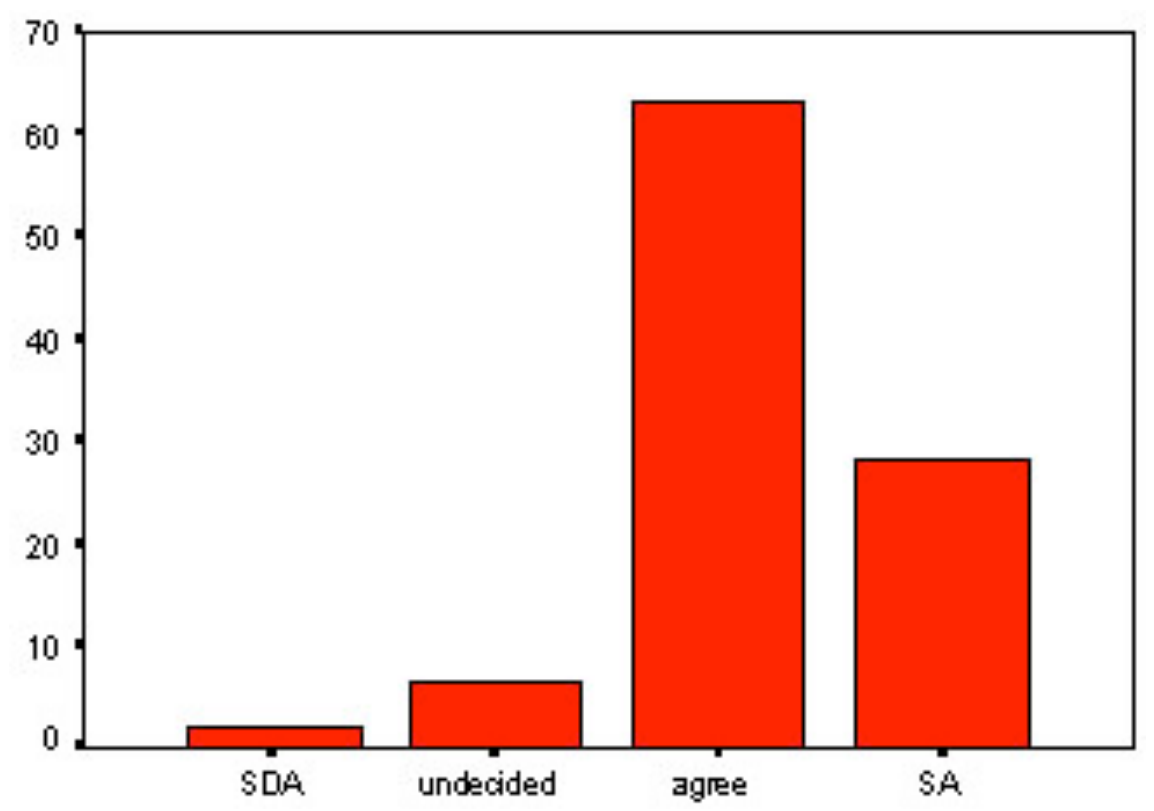

Figure 5: Percentage response on a survey scale for a "Creative and Critical thinking" item in this category (Project allowed me to be creative in my thinking) 


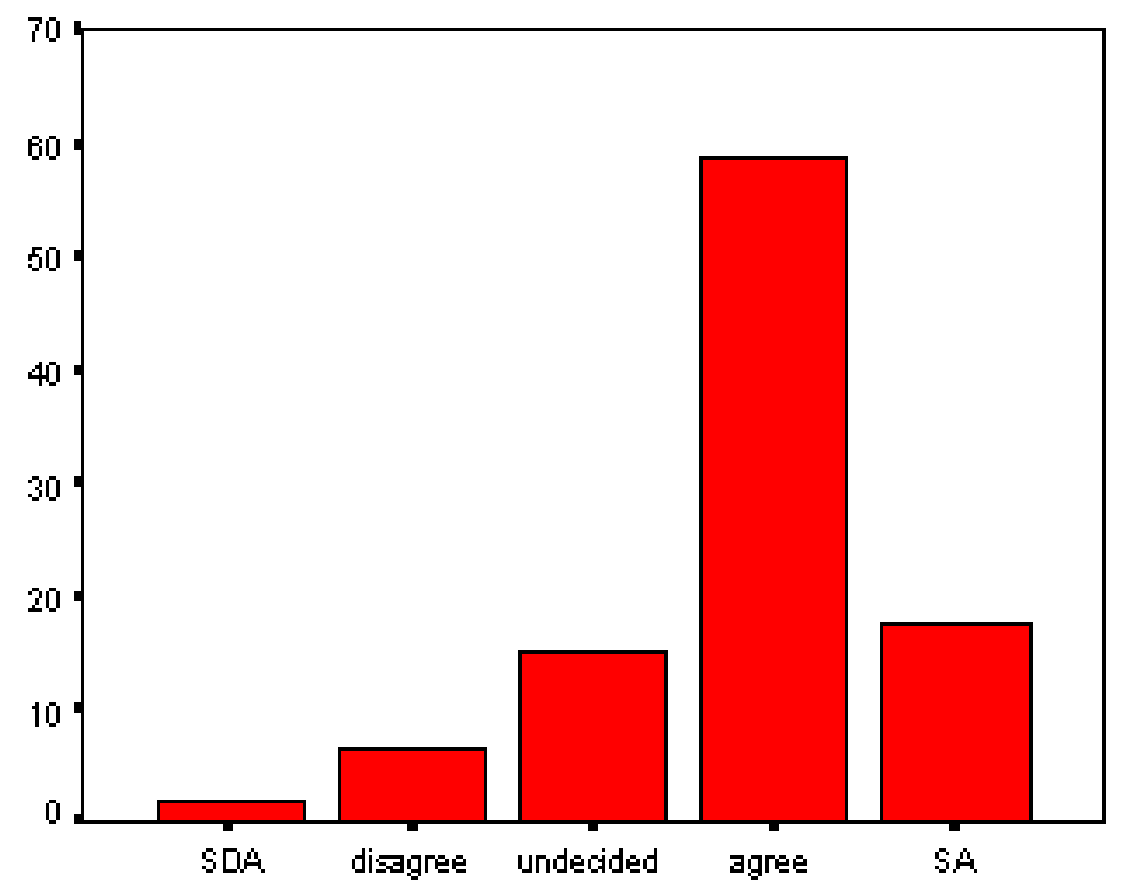

Figure 6: Percentage response on a survey scale for a "Teamwork" item in this category (Group able to achieve goals)

\section{Discussion}

The results of the survey clearly indicated that students were positive in their attitudes $(\mathrm{m}=4.09, \mathrm{p}=91 \%$; see Table 3$)$ and motivated $(\mathrm{m}=3.98$, $\mathrm{p}=76 \%$; see Table 3) towards developing a multimedia project and in working in a team $(\mathrm{m}=3.83, \mathrm{p}=78 \%$; see Table 2$)$. The highest rated items on the survey concerned the use of multimedia in the project $(\mathrm{m}=4.15$, $\mathrm{p}=91 \%$; see Table 3$)$, the ability to be creative $(\mathrm{m}=4.15, \mathrm{p}=91 \%$; see Table 1$)$ and the challenge that the project posed to them $(\mathrm{m}=4.17, \mathrm{p}=91 \%$; see Table 3). This is possibly due to the fact that these students were able to express their ideas with a combination of media elements and bring to the project innovative ideas harnessed from their group discussions.

It was also observed that students were able to develop their critical thinking skills $(\mathrm{m}=3.98, \mathrm{p}=83 \%$; see Table 1) through their planning, organising and research activities, and the translation of their ideas from the storyboard to the electronic medium. For many of the groups, gathering information on their chosen topics involved interviewing people 
and going to the actual site. This meant that students would have to develop their communication and presentation skills, and effectively select the appropriate information to display in the electronic application.

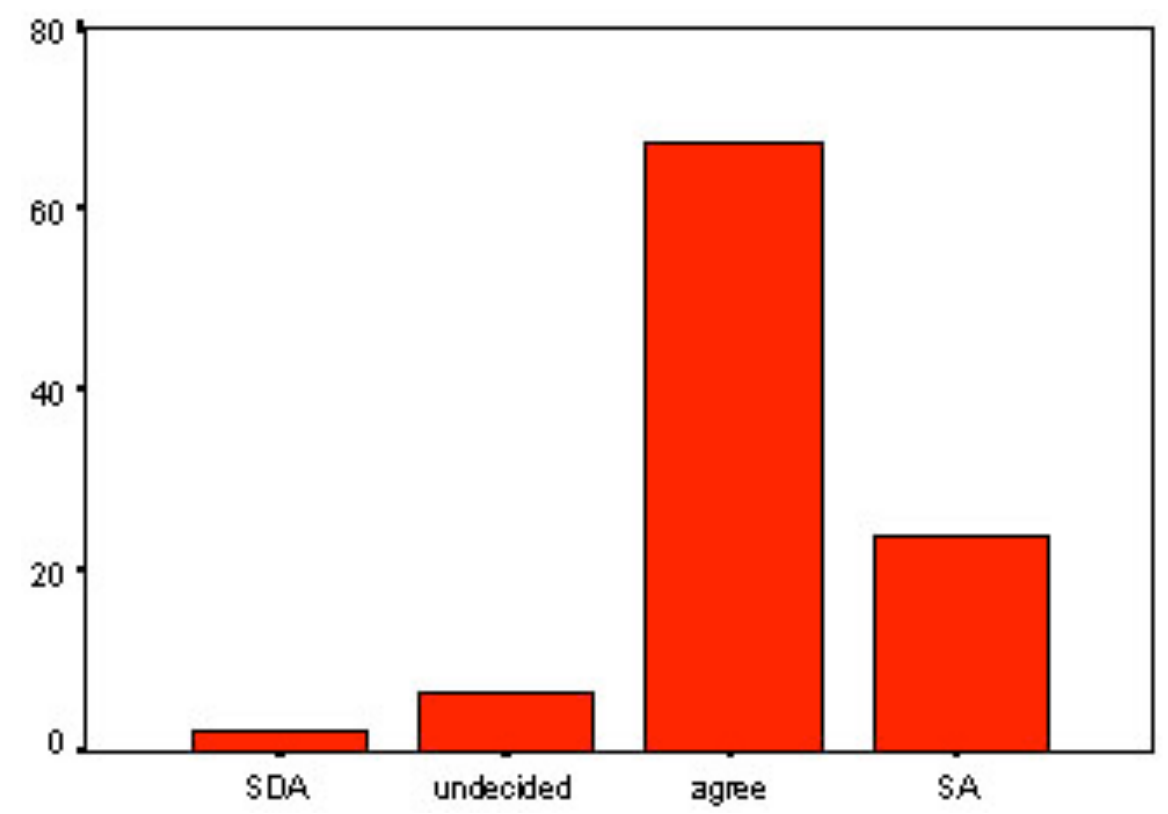

Figure 7: Percentage response on a survey scale for one item in this category (Team better able to represent concept using digital media)

Working in a team also rated favourably in the survey $(\mathrm{m}=3.83, \mathrm{p}=76 \%$; see Table 2), indicating that students found teamwork necessary for them to achieve team goals and complete their projects and to take advantage of other team members' skills and expertise. They were thus able to develop interpersonal skills and take part in brainstorming and group discussion activities in the decision making process. Many expressed the ability to work through their problems via group discussions as integral to the successful completion of projects and achievement of their group goals.

Results also showed that students were able to enhance their understanding $(\mathrm{m}=3.98, \mathrm{p}=89 \%$; see item 3 in Table 1$)$ and increase their knowledge in interdisciplinary topics $(m=3.98, p=89 \%$; see item 1 in Table 1 ) and familiarised themselves with the vocabulary of multimedia, its terms and interpretations. They were able to learn about project planning and development, and select the appropriate hardware and software application for their development, skills important in a real world setting. And through working with an authoring tool and using other applications 
to build their projects, students were able to improve their technical skills in multimedia technology ( $\mathrm{m}=3.85, \mathrm{p}=76 \%$; see Table 2$)$ and incorporate interactive features into their presentations. Many felt satisfied with their own contribution to teamwork ( $\mathrm{m}=3.98, \mathrm{p}=82 \%$; see Table 2 ).

Finally, through this project, students were able to experience a real world situation that was meaningful to them, and develop skills such as teamwork, collaboration, cooperation, critical thinking skills, that would be important to them in their future careers. This is in line with Agnew, Kellerman and Meyer's (1996) position that multimedia technology greatly influences a student's learning process.

\section{Conclusion}

Multimedia technology is becoming increasingly popular in education as a means to motivate students in their learning and to provide them with many ways to express their ideas and display their information. It also allows the Malaysian teacher the flexibility to present their curriculum in an innovative manner. In the constructivist learning mode, the teacher becomes a facilitator, a consultant or guide on the side, helping students to access, organise and obtain information to provide solutions to the problems. This learning process enables a knowledge based learning community to be created whereby students, peers and teacher share knowledge and assist one another in the acquisition and transfer of knowledge. This complex relationship has been illustrated by the author in creating a conceptual model showing the instructional relationship between the teacher, students and the role played by technology, as shown in Figure 1.

In this multimedia mediated constructivist based learning environment, student learning, in particular, the learning process, becomes the main focus, not the content, teacher or the technology used, which played only supportive roles. In this learning process, however, it can be seen that technologies such as the computers, multimedia authoring tools and the World Wide Web can have a profound effect on students' learning process.

In this multimedia mediated learning process, which is illustrated in Figure 2, students were able to use various media forms to present information, thus helping them to improve their presentation skills and communications styles, which are so important in the workplace today. Students became active seekers instead of passive recipients of knowledge and information. They also became motivated in their study and learnt to apply what they have learned previously in solving authentic problems. Learning by doing deepened their understanding of the subject matter. 
This constructivist mode of learning also enabled students to work in teams and solve problems collaboratively, which strongly emphasised Vygotsky's (1978) social aspects of learning and his concept of the ZPD, where the teacher and more capable peers assisted and empowered students in their learning and completion of their projects. Students also learned to use critical thinking skills like analysis, synthesis, evaluation and reflection while solving authentic problems. This experience will improve their interpersonal and problem solving skills. A very important element in this mode of learning is that students not only learned the 'content' but also 'the process of learning' thus enabling them to learn 'how to learn' and become life long learners.

Overall, this paper has shown that multimedia technology can be used as an efficient instructional tool in creating a constructivist based learning environment in a Malaysian classroom, whereby students can learn to inculcate interpersonal and collaborative learning skills into students in a learning community. The multimedia mediated constructivist learning model created, as shown Figure 2, was able to enhance student learning and a learning process in which students participated actively in a media rich environment and in an innovative manner. At the same time, the learning model can be employed to cultivate the mental and social construction of knowledge as enunciated in the learning theories of Piaget (1952) and Vygotsky (1978). The feedback and reactions of these students positively enhances Malaysia's objective of incorporating ICT and multimedia into the classrooms and inculcating students with the necessary skills to meet the demands of 21st century industries.

\section{References}

Agnew, P. W., Kellerman, A. S., and Meyer, J. (1996). Multimedia in the Classroom. Allyn and Bacon, Boston.

Bates, A. W. (2000). Managing Technological Change. Jossey-Bass: San Francisco.

Bruner, J. S. (1985). Models of the learner. Educational Researcher, 14(6), 5-8.

Cook, J. \& Cook, L. (1998). How technology enhances the quality of studentcentred learning. Quality Progress, 31(7).

Cunningham, D.J., Duffy, T.M. \& Knuth, R. (1993). The textbook of the future. In C. McKnight, A. Dillion \& J. Richardson (Eds) Hypertext: A Psychological Perspective. Ellis Harwood.

Dewey, J. (1896). The reflex arc concept of psychology. Psychology Review, 3, 357370.

Diamond, R.M. (1998). Designing and Assessing Courses and Curricula. Jossey-Bass: San Francisco, pp. 144. 
Duffy, T. M. and Jonassen, D. H. (1991). Constructivism: New implications for instruction technology. Educational Technology, May, pp. 7-12.

Hung, D. (2001). Design principles for web-based learning: Implications from Vygtskian thought. Educational Technology, May-June, pp.33-40.

Johns, J.F. (1999). Web-based practice environments to teach mechanical skills. Interactive Multimedia Electronic Journal of Computer-Enhanced Learning (IMEJ), 1(1) (May). [verified 1 Aug 2003] http:/ / imej.wfu.edu/articles/1999/1/01/index.asp

Jonassen, D. H. (1994). Thinking Technology: Towards a Constructivist Design Method, Educational Technology, April, pp. 34-37.

Jonassen, D. H., Peck, K. L. and Wilson, B. G. (1999). Learning with Technology: A Constructivist Perspective. Merrill/Prentice Hall, New Jersey.

Kachian, C. and Wieser, P. (1999). You can almost feel the music: Redesigning a course for new media delivery. Interactive Multimedia Electronic Journal of Computer-Enhanced Learning (IMEJ), 1(1) (May). [verified 1 Aug 2003] http: / / imej.wfu.edu/articles / 1999/1/11/index.asp

Mat, J. (2000). Technology in the Malaysian Education System. e-learning 2000: Accelerating e-Learning Towards Higher Education Value, Malaysian International Conference E Exhibition on Electronic Learning 2000, Kuala Lumpur, May 25.

Oliver, K. (2000). Methods for developing constructivist learning on the Web. Educational Technology, November-December.

Orlich, D. C., Harder, R. J., Callahan, R.C. and Gibson, H.W. (1998). Teaching Strategies: A Guide To Better Instruction. Houghton Mifflin Co., New York.

Papert, S. (1980). Mindstorms: Children, computers, and powerful ideas. New York: Basic Books.

Piaget, J. (1952). The origins of intelligence in children. New York: International Universities Press.

Roblyer, M.D. and Edwards, J. (2000). Integrating Educational Technology into Teaching (2nd Edition). Merrill/ Prentice-Hall, New Jersey.

Tapscott, D. (1999). Educating the net generation. Educational Leadership, 56(5).

Thornburg, D. (1995). Student-centred learning. Electronic Learning, 14(7).

Vygotsky, L. S. (1978). Mind in society, Cambridge, MA: Harvard University Press.

Vygotsky, L. S. (1987). Thinking and speech. In R.W. Lieber \& A.S. Carton (Eds.), The collected works of L.S. Vygotsky. New York: Plenum.

Ken Neo Tse-Kian, Lecturer

Centre for Innovative Education (CINE)

Faculty of Creative Multimedia,

Multimedia University,

Cyberjaya, Selangor, Malaysia

Tel: +603 56357817 Fax: +603 56357817

Email: kneo@pc.jaring.my 